\title{
Yield of gherkin in response to doses of bovine manure
}

\author{
Arnaldo Nonato P de Oliveira; Ademar P de Oliveira; Francisco de Assis P Leonardo²; Iordam da S \\ Cruz; Damiana F da Silva \\ ${ }^{1}$ UFPB-CCA, C. Postal 02, 58397-000 Areia-PB, ademar@ pesquisador.cnpq.br
}

\begin{abstract}
Considering the importance of gherkin in Northeastern Brazil, studies focusing on increasing its quality and yield are powerful tools to improve people social and economical condition in this region. The effects of doses of bovine manure were evaluated in gherkin yield in an experiment using cultivar Nordestino, from May to September 2006, at the Federal University of Paraíba, in Areia County, Paraíba State, Brazil. The experimental design was randomized complete blocks, with five treatments $\left(0 ; 10 ; 20 ; 30\right.$, and $\left.40 \mathrm{t} \mathrm{ha}^{-1}\right)$ of bovine manure, in four replications. The working area in each experimental plot corresponded to $80 \mathrm{~m}^{2}$, including 20 plants, with $2.0 \times 2.0 \mathrm{~m}$ spaces. The highest number of fruits per plant (30) was achieved with $32.2 \mathrm{t} \mathrm{ha}^{-1}$ of bovine manure. Both fruit production per plant and fruit yield increased with doses of bovine manure, with maximum values of respectively $1,306 \mathrm{~g}$ and $19.5 \mathrm{tha}^{-1}$, when $40 \mathrm{tha}$ ${ }^{1}$ of bovine manure were used.
\end{abstract}

Keywords: Cucumis anguria L., organic fertilization, yield.

\section{RESUMO}

\section{Produção do maxixeiro em resposta a doses de esterco bovino}

Estudos que visem o aumento do rendimento e da qualidade do maxixe são importantes ferramentas para melhorar a condição sócioeconômica da região Nordeste, uma vez que esta hortaliça tem grande importância na região. Com o objetivo de avaliar o efeito de doses de esterco bovino no rendimento do maxixe, instalou-se um experimento utilizando a cultivar Nordestino, de maio a setembro/06, na Universidade Federal da Paraíba, em Areia (PB). O delineamento experimental utilizado foi blocos casualizados, com cinco tratamentos: 0; $10 ; 20 ; 30$ e $40 \mathrm{t} \mathrm{ha}^{-1}$ de esterco bovino, em quatro repetições. Utilizaram-se parcelas úteis com 20 plantas, espaçadas de 2,00 x 2,00 m, com área de $80 \mathrm{~m}^{2}$. A dose de 32,2 $\mathrm{t} \mathrm{ha}^{-1}$ de esterco bovino foi responsável pelo número máximo de 30 frutos por planta. A produção de frutos por planta e a produtividade de frutos aumentaram com a elevação das doses de esterco bovino, com valores máximos de 1.306 g e 19,5 $\mathrm{t} \mathrm{ha}^{-1}$, respectivamente, na dose de $40 \mathrm{t} \mathrm{ha}^{-1}$.

Palavras-chave: Cucumis anguria $\mathrm{L}$, adubação orgânica, produção.

\section{(Recebido para publicação em 8 de janeiro de 2008; aceito em 27 de fevereiro de 2009)}

\section{(Received in January 8, 2008; accepted in February 27, 2009)}

$\mathrm{G}$ herkin is a vegetable of African origin, which is very popular in the Northern and Northeastern regions of Brazil. Fruits have no bitterness and vary in size and amount of thorns, with average weight around $30 \mathrm{~g}$ (Pimentel, 1985). It is usual to find spontaneous gherkin plants growing in other crop fields. Fruits harvested out of those plants are home-used and also traded, when there is demand. Fruits are consumed immature and prepared in natura (salads), canned (pickles), or cooked (boiled, soups, etc.). In general, it is a vegetable underused as food in Brazil and elsewhere (Robinson \& Decker-Walters, 1997; Bates et al., 1999).

Gherkin does not require soils of high fertility and adapts better to sandy soils. Most of the farmers grow it without fertilization, relying on the residues of the previous crop. However, in poor soils it is recommended to add fertilizers (Filgueira, 2000). In Brazil, the use of organic fertilization in agriculture is increasing due to its beneficial effects over soil physical properties. In addition, organic fertilization raises nutrient availability, either at once or residually. These properties lead to increments on crop yield and allow producing plants with standards as high as those grown exclusively on mineral fertilizers (Santos et al., 2001).

The valuable effects of organic fertilization have been related to the nutrient content of the organic manure and also to the changes it produces on soil physical properties. The use of organic manures improves especially soil aggregation, which, in its turn, influences soil infiltration and water retention capacity, as well as drainage, aeration, temperature, and root penetration. Therefore, crop response to organic fertilization can not be attributed exclusively to the supply of nutrients, but also to the improvement in the uptake conditions (Varanine et al., 1993). The use of adequate doses of bovine manure may supply plant demands on macronutrients (Camargo, 1984). On the other hand, its indiscriminate use may increase soil Nitrogen contents up levels that cause salinization, due to the elevation of electric conductivity. In such a situation, misbalance in plant nutrition and decreases in yield are expected (Silva et al., 2000).

There are few reports on the organic fertilization of gherkin. Pimentel (1985), for conditions of Northern Brazil, advises to use 100 to $200 \mathrm{~g}$ of poultry manure per hole before planting. Modolo \& Costa (2003), for conditions of Southeastern Brazil, recommend to complete the organic fertilization 30 days before sowing, using 3 to 4 or 5 to $15 \mathrm{t}$ $\mathrm{ha}^{-1}$ of respectively poultry and bovine manure. This work was carried out mainly due to the lack of recommendation of organic fertilization for gherkin in conditions similar to those of Areia County, in the State of Paraíba. Our objective was to evaluate the changes in gherkin yield as function of the use of different doses of bovine manure.

\section{MATERIAL AND METHODS}

The trial was carried out at an experimental field from the Federal 
University of Paraíba, at Areia County (06 $\left.{ }^{\circ} 18^{\prime} 12^{\prime \prime S}, 32^{\circ} 18^{\prime} 15^{\prime \prime} \mathrm{W}, 560 \mathrm{mos}\right)$, from May to September 2006, in a typical Quartz psamment soil (Embrapa, 1999), loam sandy texture, with the following chemical and physical characteristics: $\mathrm{pH}\left(\mathrm{H}_{2} \mathrm{O}\right)=6.9 ; \mathrm{P}($ resine $)=11.24 \mathrm{mg} \mathrm{dm}^{-3}$; $\mathrm{K}=54.12 \mathrm{mg} \mathrm{dm}^{-3} ; \mathrm{Al}^{+3}=0.00 \mathrm{cmol} \mathrm{dm}^{-}$ 3. $\mathrm{Ca}^{2+}=3.35 \mathrm{cmol}_{\mathrm{c}} \mathrm{dm}^{-3} ; \mathrm{Mg}^{2+}=0.65$ $\mathrm{cmol}_{\mathrm{c}} \mathrm{dm}^{-3} ; \mathrm{Na}^{+}=0.07 \mathrm{cmol}_{\mathrm{c}} \mathrm{dm}^{-3} ; \mathrm{H}^{+}$ $\mathrm{Al}^{+3}=2.56 \mathrm{cmol}_{\mathrm{c}} \mathrm{dm}^{-3} ; \mathrm{SB}=4.21 ; \mathrm{CTC}=$ 6.77 ; and organic matter $=14.93 \mathrm{~g} \mathrm{~kg}^{-1}$ (Embrapa, 1997); sand $=841.50 \mathrm{~g} \mathrm{~kg}^{-1}$; silt $=88.00 \mathrm{~g} \mathrm{~kg}^{-1}$; clay $=70.50 \mathrm{~g} \mathrm{~kg}^{-1}$; global density $=1.37 \mathrm{~g} \mathrm{~cm}^{-3}$; density of particles $=2.61 \mathrm{~g} \mathrm{dm}^{-3}$; and total porosity $=0.47 \mathrm{~m}^{3} \mathrm{~m}^{-3}$. The bovine manure used in this work had the following chemical characteristics: $\mathrm{P}=5.2 \mathrm{~g} \mathrm{~kg}^{-1} ; \mathrm{K}=4.9 \mathrm{~g}$ $\mathrm{kg}^{-1} ; \mathrm{N}=3.2 \mathrm{~g} \mathrm{~kg}^{-1}$; organic matter $=$ $112.07 \mathrm{~g} \mathrm{dm}^{-3}$; and $\mathrm{C} / \mathrm{N}$ ratio $=14 / 1$. Before planting the soil was ploughed and harrowed. Then, the planting holes $(30 \times 30 \mathrm{~cm})$ were opened.

The experimental design was complete blocks at random, with five treatments $\left(0 ; 10 ; 20 ; 30\right.$, and $40 \mathrm{tha}^{-1}$ of bovine manure) and four replications. The experimental plots comprised 20 plants; with spaces of $2.0 \times 2.0 \mathrm{~m}$. Fertilization consisted solely on the doses of bovine manure, applied into the planting holes seven days before sowing, four seeds per hole. Cultivar Nordestino (Hortivale) was used. Thinning to two plants per hole was carried out 15 days after sowing. Crop practices were those usually employed in gherkin growing, including sprinkling irrigation, with three times a week shifts for the absence of precipitation. Weeding was carried out using hoes, aiming at keeping the field constantly free from weeds.

Immature bright green fruits were harvested every other three days, from 50 to 120 days after sowing, mounting up to 16 harvests. We assessed number of fruits and commercial yield per plant and per hectare. Commercial fruits were those with bright green color, larger than $15 \mathrm{~g}$, and without the white spot, according to Modolo \& Costa (2003). Data were used for analysis of variance and polynomial regression, calculated using the software SAEG (2000). Linear, quadratic, and cubic models were tested

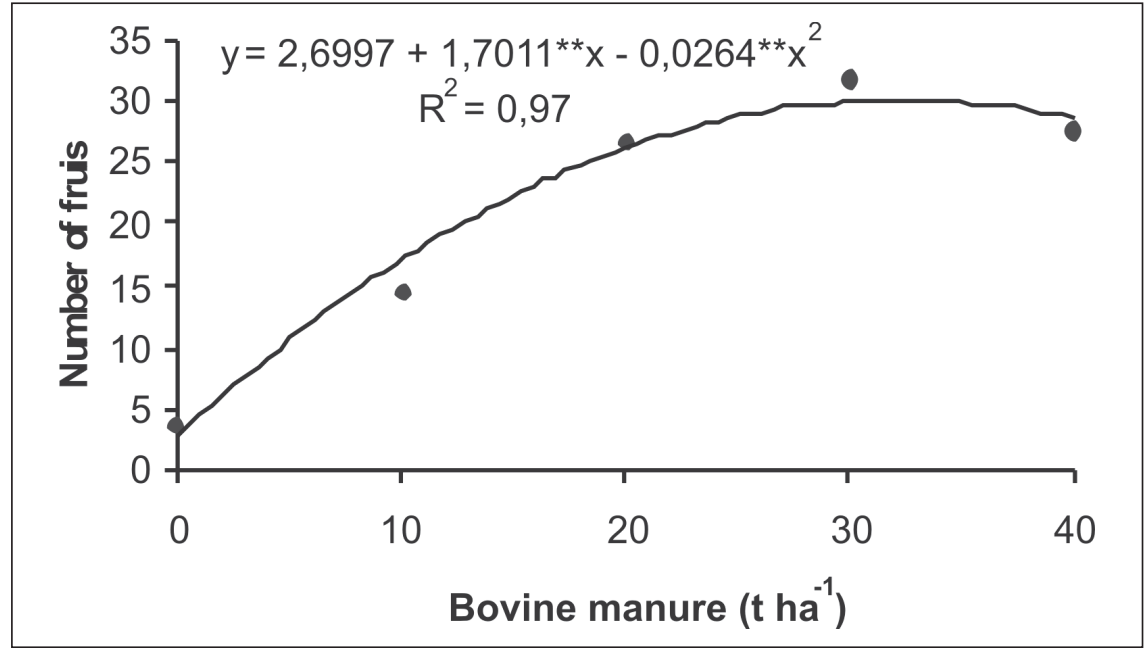

Figure 1. Number of gherkin fruits per plant as affected by doses of bovine manure (número de frutos por planta em maxixeiro em função de doses de esterco bovino). Areia, UFPB, 2006.

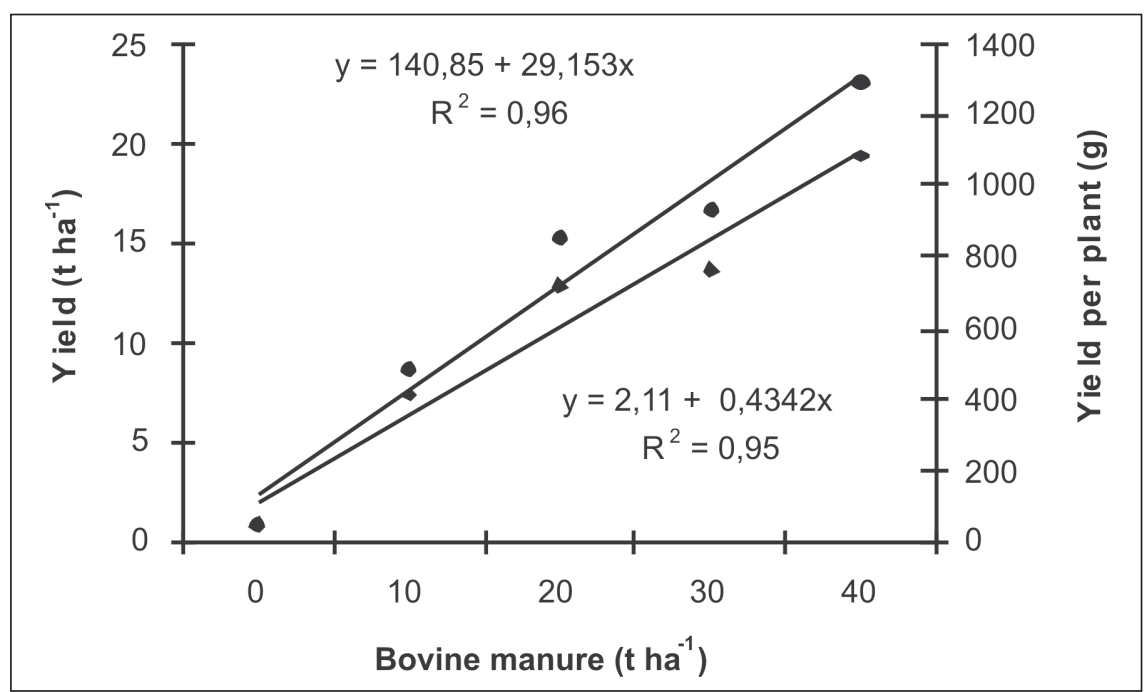

Figure 2. Gherkin fruit yield per hectare and per plant as affected by doses of bovine manure (produtividade e produção de frutos por planta em maxixeiro em função de doses de esterco bovino). Areia, UFPB-CCA, 2006.

in the regression analysis. The model with the largest determination coefficient value $\left(\mathrm{R}^{2}\right)$ was then selected.

\section{RESULTS AND DISCUSSION}

The use of bovine manure influenced significantly $(p<0.05)$ the number of fruits per plant and the yield both per plant and per hectare.

The dose $32.2 \mathrm{t} \mathrm{ha}^{-1}$ of bovine manure, estimated by deriving the regression equation (Figure 1), led to the largest number of fruits per plant (30), while the yield per plant and per hectare increased linearly with manure doses, reaching their maximum, respectively
1,306 $\mathrm{g}$ and $19.5 \mathrm{tha}^{-1}$, when $40 \mathrm{tha}^{-1}$ of bovine manure were applied (Figure 2).

The point of maximum in the yield curve was not reached under the experimental conditions. Even then, the highest observed yield corresponded to an impressive increment of $17.4 \mathrm{tha}^{-1}$ in yield in relation to the treatment where no bovine manure was used. It should be pointed also that the highest observed yield exceeded the gherkin yield at the state of Maranhão, defined by Martins (1986) as ranging from 8 to $16 \mathrm{t} \mathrm{ha}^{-1}$, as well as that for the State of São Paulo, established at $12 \mathrm{t} \mathrm{ha}^{-1}$ (Melo \& Trani, 1998). In addition, the highest fruit yield we observed was by far larger 
than $5 \mathrm{t} \mathrm{ha}^{-1}$, reported by Filgueira (2000) as a reasonable yield for gherkin. Thus, our results are strong evidence that it is possible to achieve good gherkin production at the microregion of Areia County, where there is no previous report of gherkin average yields to.

The positive response of gherkin to bovine manure may have occurred as consequence of a balanced supply of nutrients to plants during their development, from both the manure and the soil. The linear increase in yield with manure doses clearly shows that the bovine manure was an efficient organic amendment for gherkin growing. It is known that bovine manure, when supplied adequately, is effective in delivering macronutrients to plants, due to the increase in the contents of available P and K (Silva et al., 1999).

Although the experiment was carried out in a soil with low $\mathrm{P}$ contents, $\mathrm{K}$ contents were at medium rate. Therefore, we believe that bovine manure boosted gherkin yield not only due to nutrient supply, but also due to the improvement in another constituents of soil fertility. It is known that both water availability and soil structure benefits from the development of humus-clay complexes, with consequent increase in the CEC (Yamada \& Kamata, 1989), which results in a more favorable environment for the uptake of the nutrients originally present in the soil.

\section{ACKNOWLEDGMENTS}

Authors thank Prof. Sheila C de Farias for revising the Abstract, and also the Ministry of Agriculture, Livestock, and Food Supply officers Francisco de C Azevedo, José B de Souza, Francisco S do Nascimento e Genival G da Silva, who make the field work possible. Ademar P de Oliveira holds a CNPq (The National Council for Scientific and Technological Development) Productivity in Research grant. Iordam da S Cruz holds a CNPq fellowship for technical assistance.

\section{REFERENCES}

BATES DM; ROBINSON RW; JEFREY, C. 1999. Biology and utilization of the Cucurbitaceae. Ithaca: Cornel University Press. 485 p.

CAMARGO LS. 1984. As hortaliças e seu cultivo. Campinas: Fundação Cargill. p. 2829.

EMBRAPA. 1997. Serviço Nacional de Levantamento e Conservação do Solo. Manual de métodos de análise de solo. Rio de Janeiro: 212 p.

EMBRAPA. 1999. Centro Nacional de Pesquisa do Solo. Sistema Brasileiro de Classificação de Solos. Brasília: 412 p.

FILGUEIRA FAR. 2000. Novo manual de olericultura: agrotecnologia moderna na produção e comercialização de hortaliças. Viçosa: UFV. 402 p.

MARTINS MAS. 1986. Maxixe (Cucumis anguria L) e seu cultivo em São Luís do Maranhão. São Luís: EMAPA. (Documento, 8).
MELO AMT; TRANI PS. 1998. Maxixe In: MELO AMT; DeMARIA IC; FURLANI AMC (ed). Instruções agrícolas para as principais culturas econômicas. Campinas: Instituto Agronômico. 393 p. (IAC. Boletim técnico, 209).

MODOLO VA; COSTA CP. 2003. Maxixe: uma hortaliça de tripla forma de consumo. Piracicaba: ESALQ - Divisão de biblioteca e documentação, 20 p (Série produtor Rural, 19).

PIMENTEL AAMP. 1985. Olericultura no Trópico úmido. São Paulo: Agronômica Ceres. 321p.

ROBINSON, RW; DECKER-WALTER, DS. 1997. Cucurbits. New york: CAB International. $225 \mathrm{p}$.

SAEG - 2000. Sistema para análise estatística, versão 8.0. Viçosa-MG: Fundação Artur Bernardes.

SANTOS RHS; SILVA F.; CASALI VWD; CONDE AR. 2001. Conservação póscolheita de alface cultivada com composto orgânico. Pesquisa Agropecuária Brasileira 36: 521-525.

SILVA FN; MAIA SSS; OLIVEIRA M. 2000. Doses de matéria orgânica na produtividade da cultura da alface em solo eutrófico na região de Mossoró, RN. Horticultura Brasileira 18: 723-724. (Suplemento).

SILVA NF; FERREIRA FA; FONTES PCR. SEDIYAMA MAN. 1999. Crescimento e estado nutricional de abóbora híbrida em função de adubação orgânica e mineral. Horticultura Brasileira 17: 193-200.

VARANINE Z; PINTON R; BIASE MG; ASTOLFI S; MAGGIONI A. 1993. Low molecular weight huimic substances stimulate $\mathrm{H}^{+}$- ATPase activity of plasma membrane vesicles isolated from oat (Avena sativa L) roots. Plant and soil 153: 61-69.

YAMADA H. KAMATA H. 1989. Agricultural technological evaluation of organic farming and gardening I. Effects of organic farming on yields of vegetables and soil physical and chemical properties. Bulletin of the Agricultural Research Institute of Kanagawa Prefecture 130: 1-13. In: Horticultural Abstract 59: 938-939. 